\title{
A Fast Metals Recovery Method for the Synthesis of Lithium Nickel Cobalt Aluminum Oxide Material from Cathode Waste
}

\author{
Soraya Ulfa Muzayanha ${ }^{1}$, Cornelius Satria Yudha ${ }^{1}$, Adrian Nur ${ }^{1}$, Hendri Widiyandari ${ }^{2}$, \\ Hery Haerudin ${ }^{3}$, Hanida Nilasary ${ }^{3}$, Ferry Fathoni ${ }^{3}$ and Agus Purwanto $1, * \mathbb{D}$ \\ 1 Department of Chemical Engineering, Faculty of Engineering, Universitas Sebelas Maret, Jl. Ir. Sutami 36 A, \\ Surakarta, Central Java 57126, Indonesia; sorayamuzayanha@student.uns.ac.id (S.U.M.); \\ cornelyudha@student.uns.ac.id (C.S.Y.); adriannur@staff.uns.ac.id (A.N.) \\ 2 Department of Physics, Faculty of Mathematic and Natural Science, Universitas Sebelas Maret, Jl. Ir. Sutami \\ 36 A, Surakarta, Central Java 57126, Indonesia; hendriwidiyandari@staff.uns.ac.id \\ 3 Research \& Technology Center, PT. PERTAMINA (Persero), Gedung Kwarnas 11th Floor, Jl. Medan Merdeka \\ Timur No. 6, Jakarta Pusat 10110, Indonesia; hery.haerudin@pertamina.com (H.H.); \\ hanida.nilasary@pertamina.com (H.N.); ferry.fathoni@pertamina.com (F.F.) \\ * Correspondence: aguspur@uns.ac.id; Tel.: +62-0271-632112
}

Received: 2 May 2019; Accepted: 22 May 2019; Published: 27 May 2019

check for updates

\begin{abstract}
An approach for a fast recycling process for Lithium Nickel Cobalt Aluminum Oxide (NCA) cathode scrap material without the presence of a reducing agent was proposed. The combination of metal leaching using strong acids $\left(\mathrm{HCl}, \mathrm{H}_{2} \mathrm{SO}_{4}, \mathrm{HNO}_{3}\right)$ and mixed metal hydroxide co-precipitation followed by heat treatment was investigated to resynthesize NCA. The most efficient leaching with a high solid loading rate $(100 \mathrm{~g} / \mathrm{L})$ was obtained using $\mathrm{HCl}$, resulting in $\mathrm{Ni}, \mathrm{Co}$, and $\mathrm{Al}$ leaching efficiencies of $99.8 \%, 95.6 \%$, and $99.5 \%$, respectively. The recycled NCA (RNCA) was successfully synthesized and in good agreement with JCPDS Card \#87-1562. The highly crystalline RNCA presents the highest specific discharge capacity of a full cell (RNCA vs. Graphite) of $124.2 \mathrm{mAh} / \mathrm{g}$ with capacity retention of $96 \%$ after 40 cycles. This result is comparable with commercial NCA. Overall, this approach is faster than that in the previous study, resulting in more efficient and facile treatment of the recycling process for NCA waste and providing 35 times faster processing.
\end{abstract}

Keywords: NCA; Li-ion battery; hydrometallurgical; recycle; resynthesis

\section{Introduction}

In these advanced times, Lithium ion (Li-ion) batteries have become the prime technology for energy storage in portable electronics such as laptops, smartphones, powerbanks, and electric vehicles. Previously, the most commonly used and successfully commercialized Li-ion battery used $\mathrm{LiCoO}_{2}$ (LCO), but there are too many limitations of LCO, such as the high cost of cobalt and poor thermal stability. Recently, other types of Li-ion battery were found, such as $\mathrm{Li}_{0.8} \mathrm{Co}_{0.15} \mathrm{Al}_{0.05} \mathrm{O}_{2}$ (NCA), $\mathrm{LiNi}_{0.33} \mathrm{Co}_{0.33} \mathrm{Mn}_{0.33} \mathrm{O}_{2}$ (NMC), and $\mathrm{LiFePO}_{4}$ (LFP) [1], and they became promising candidates as substitutes for LCO. The demand for Li-ion batteries increased significantly from 1990 to 2016 [2]. However, increasing Li-ion battery usage results in the accumulation of spent Li-ion batteries (Libs) which can cause serious environmental issues [2]. Recycling spent Li-ion batteries could be a brilliant way to maintain sustainability of this active material for industries that rely on batteries. Recycling would involve the recovery of valuable metals followed by regeneration to a new active material. Among the three recent types of Li-ion Battery, NCA has attracted the most attention for use in Li-ion batteries due to its high potential relative to $\mathrm{Li}(3.7 \mathrm{~V})$ which promotes high energy density and high 
capacity characteristics. Because of its superior performance, TESLA use NCA batteries for their Electric Vehicles (EVs) [1,3]. It is predicted that the demand for NCA will increase to 39,000 tons in 2025 [2]. Recycling processes could also minimize the cost of raw materials while reducing the threat that the waste poses for the environment.

The recycling processes for Li-ion battery waste (spent libs or scrap) are divided into three steps, namely, pretreatment, metal extraction, and product preparation [4]. The aim of the pretreatment process is to separate the cathode material from other components like Al foil, plastics, Fe, etc., which involves a mechanical process [5], solvent dissolution [6-8] or $\mathrm{NaOH}$ dissolution [9-11], ultrasonic-assisted separation $[12,13]$, etc. The metal extraction is a significant step in the recycling process which changes the solid metals into their solution state or alloy form to facilitate metal recovery. The three types of metal extraction techniques are hydrometallurgical [14,15], pyrometallurgical [16,17], and bio-hydrometallurgical [18-20]. The hydrometallurgical process is the most commonly used process due to its advantages such as ease of processing, lower energy demands, and a highly pure product with fewer gas emissions [12,21]. Leaching is a main step in the hydrometallurgical process whereby acids are used to dissolve the valuable metals into solution. Various inorganic acids such as $\mathrm{HCl}, \mathrm{H}_{2} \mathrm{SO}_{4}$, and $\mathrm{HNO}_{3}$ [21-24] and organic acids such as citric acids, malic acids, oxalic acids, etc. [25-28] are usually used as the leaching agent (leachant) to leach out the valuable metals contained in the material. The inorganic acids present a satisfactory performance during leaching and achieve higher efficiency of metal extraction than organic acids [29]. Techniques that are used to prepare the final products from the leaching filtrate include solvent extraction [10,30-33], electrochemical techniques [34-36], selective precipitation [21,37-40], and co-precipitation [41-43]. Among these, co-precipitation is the most efficient technique for the recovery of more than one metal (mixed metal) due to a higher level of homogeneity and spherical/sphere-like products [44]. Based on our literature study, the hydrometallurgical method has been successfully applied to the recycling and resynthesis of LCO, LFP, and NMC $[7,9,41,45]$. However, there remains a lack of research into the recycling and resynthesis of NCA material.

Previously, Joulie et al. [21] investigated the leaching efficiency using strong acids and the recovery of metals (nickel and cobalt) via selective precipitation processing for which the optimum leaching result was given by $4 \mathrm{M} \mathrm{HCl}, 90^{\circ} \mathrm{C}, 18 \mathrm{~h}$, and a solid loading rate of $50 \mathrm{~g} / \mathrm{L}$. However, the leaching process needed a long processing time with a low solid loading rate, which is inefficient in terms of time and energy. Then, Sandhya et al. [8] proposed a synthesis process for material for anodes that involved mixed oxides of nickel and cobalt from spent NCA batteries using concentrated $\mathrm{HCl}$ leaching and co-precipitation with $\mathrm{NaOH}$ followed by microwave heat treatment. However, complex equipment and a large amount of energy were also required in the recycling process. No report has been found regarding the resynthesis of NCA material from a leaching stream of NCA waste, which is one of the most promising cathode materials with features such as specific high capacity, high energy density, and a long life cycle [21,46].

Hence, in this work, we propose a fast process for the resynthesis of NCA material via mixed metal hydroxide precipitation of nickel, cobalt, and aluminum from a leaching stream of NCA scrap. NCA scrap is unused and/or residual cathode film that is produced in the cutting process during the battery production process. The resynthesis of NCA material from waste has not been found in the literature. The leaching process used various strong acids $\left(\mathrm{HCl}, \mathrm{H}_{2} \mathrm{SO}_{4}, \mathrm{HNO}_{3}\right)$ without the presence of a reducing agent. The effect of heat treatment before the leaching process on powder separated from $\mathrm{Al}$ foil was studied. Unlike the previous study by Joulie et al., this work proposed the recycling and also resynthesis of NCA material with a high solid loading rate of $100 \mathrm{~g} / \mathrm{L}$ of leaching, which is necessary to enhance the productivity of the leachate and the final product. Based on our best knowledge, this approach has never been reported by other researchers. Fast, efficient, and easy processing will be served using this approach. The electrochemical performance was tested using full cell batteries using graphite as an anode. In this work, the performance of the recycled NCA material is comparable with that of commercial NCA; hence, a proof of concept is provided. 


\section{Materials and Methods}

\subsection{Experimental Process}

\subsubsection{Pretreatment}

NCA scrap was obtained from a Battery Manufacturing Facility which is operated by Sebelas Maret University. During battery production of the NCA type, the cutting process of the cathode film leaves some residual and/or reject film (namely, NCA scrap) which is collected for recycling. The pretreatment process for scrap is usually simpler than that for spent libs. NCA scrap contains Al foil which must be separated by immersion with agitation in an alkaline solution ( $5 \mathrm{M} \mathrm{NaOH})$ for $2 \mathrm{~h}$. The dissolved $\mathrm{Al}$ in $\mathrm{NaOH}$ is converted to sodium aluminate in the reaction shown in Equation (1):

$$
2 \mathrm{Al}_{(\mathrm{s})}+2 \mathrm{NaOH}_{(\mathrm{aq})}+2 \mathrm{H}_{2} \mathrm{O}_{(\mathrm{liq})} \rightarrow 2 \mathrm{NaAlO}_{2(\mathrm{aq})}+3 \mathrm{H}_{2(\mathrm{~g})}
$$

The active material that was peeled from the $\mathrm{Al}$ foil was filtered and washed using demineralized water to remove the remaining $\mathrm{NaOH}$, and the residue was heated at $80{ }^{\circ} \mathrm{C}$ in an oven. In order to eliminate the acetylene black and polyvinylidene difluoride (PVDF), which can slow the process of metal dissolution, the residue was calcined at $800^{\circ} \mathrm{C}$ for 2 and $4 \mathrm{~h}$. The effect of heating time was studied. The obtained powder was then ground to minimize the particle size to improve surface area contact and accelerate the reaction rate during leaching.

\subsubsection{Acid Leaching of NCA Scrap}

First, the powder was leached completely in concentrated $\mathrm{HCl}$ (Merck, Darmstadt, Germany) to determine the total concentrations of all metal ions $\left(\mathrm{Ni}^{2+}, \mathrm{Co}^{2+}\right.$, and $\left.\mathrm{Al}^{3+}\right)$. The leaching process was performed in a $500 \mathrm{~mL}$, three-necked, and round-bottomed flask. A water bath was used to maintain the desired temperature. The leaching process was conducted at a solid-to-liquid ratio of $100 \mathrm{~g} / \mathrm{L}$, an acid concentration of $4 \mathrm{M}$, temperature of $80^{\circ} \mathrm{C}$, and leaching time of $60 \mathrm{~min}$. An overhead stirrer was used for agitation during the leaching process. The leachate residue was filtered using filter bag paper. The concentrations of metal ions $\left(\mathrm{Ni}^{2+}, \mathrm{Co}^{2+}\right.$, and $\left.\mathrm{Al}^{3+}\right)$ in the leachate were measured using Atomic Absorption Spectroscopy (AAS) in order to determine the leaching efficiency. The effects of various acids ( $\mathrm{HCl}, \mathrm{HNO}_{3}, \mathrm{H}_{2} \mathrm{SO}_{4} /$ Merck, Darmstadt, Germany) and leaching behaviors were studied.

\subsubsection{Resynthesis of NCA}

The leachate from $\mathrm{HCl}, \mathrm{H}_{2} \mathrm{SO}_{4}$, and $\mathrm{HNO}_{3}$ contained metal ions $\left(\mathrm{Ni}^{2+}, \mathrm{Co}^{2+}\right.$, and $\left.\mathrm{Al}^{3+}\right)$ and was next processed by mixed metal hydroxide co-precipitation using $\mathrm{NaOH}$ (Asahi, Cilegon, Indonesia) and ammonia (Merck, Darmstadt, Germany) as the precipitant and monodentate ligand, respectively. First, the ammonia solution and $5 \mathrm{M} \mathrm{NaOH}$ were added to the $500 \mathrm{~mL}$ batch reactor. The process was controlled at $\mathrm{pH} 11-12$ and heated to a constant temperature of $60^{\circ} \mathrm{C}$ for $6 \mathrm{~h}$. At constant $\mathrm{pH}$, the aging process was conducted for $20 \mathrm{~h}$. This co-precipitation experiment used an overhead stirrer at high speed (more than $900 \mathrm{rpm}$ ). Then, the greenish precursors were filtered and washed using deionized water to eliminate the remaining $\mathrm{NaOH}$ and other impurities. The precursors were dried in an oven at $80^{\circ} \mathrm{C}$ overnight. The $-\mathrm{OH}$ precursors which resulted in the leaching processes using hydrochloric acid, nitric acid, and sulfuric acid were denoted P-HA, P-NA, and P-SA. The-OH precursor was then tested using X-ray fluorescence (D2 Phaser Bruker, Karlsruhe, Germany) to determine the metal content and Fourier Transformed Infrared Spectroscopy (Shimadzu, Japan) to identify the functional groups of the -OH precursor.

Next, the precursor was mixed with LiOH (Merck, Darmstadt, Germany) using a mortar and pestle until homogeneity was achieved. The molar ratio of Li to metal ions was adjusted to 1.03:1 using the hydroxide salts of metals. Then, the mixture was calcined at $550{ }^{\circ} \mathrm{C}$ for $6 \mathrm{~h}$ and was further sintered at $800{ }^{\circ} \mathrm{C}$ for $12 \mathrm{~h}$ under an oxygen stream in a muffle furnace. Finally, the NCA material was obtained. 
The NCA material was ground and screened into fine NCA particles (referred to here as Recycled NCA or RNCA). A flow chart of the RNCA synthesis appears in Figure 1, in which the leaching processes of RNCA using hydrochloric acid, nitric acid, and sulfuric acid are denoted RNCA-HA, RNCA-NA, and RNCA-SA.

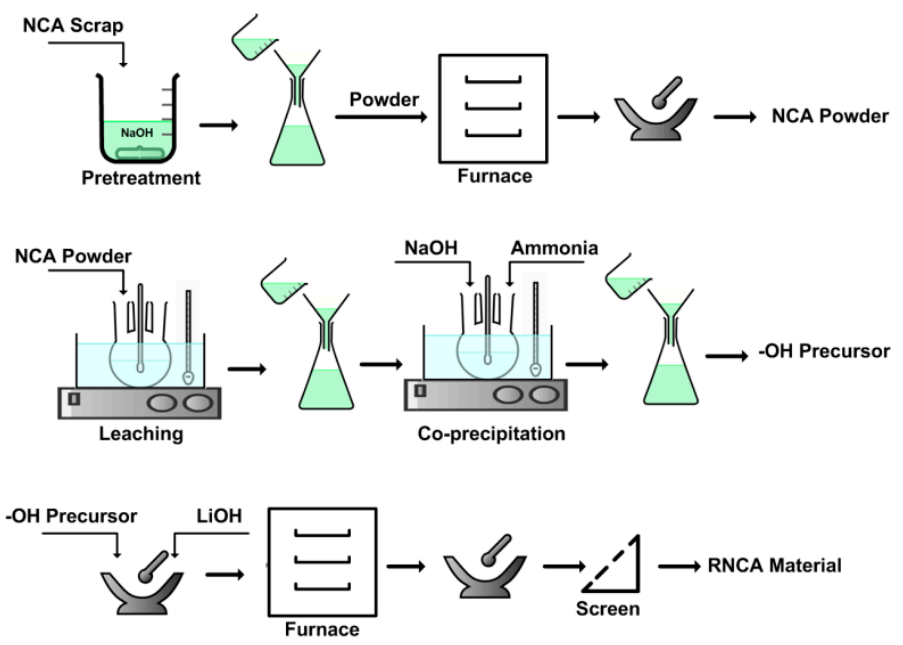

Figure 1. Flow chart of the recycled Lithium Nickel Cobalt Aluminum Oxide (RNCA) recycling process.

\subsection{Characterization and Electrochemical Testing}

The structure of the NCA crystals was investigated by X-ray diffraction (D2 Phaser Bruker, Germany) with a $2 \theta$ value that ranged from $10^{\circ}$ to $70^{\circ}$ at a $2 \theta$ increment of $0.02^{\circ}$. Scanning Electron Microscopy (Jeol JSM-6510LA, Tokyo, Japan) was used to observe the morphology of the NCA particles. The metal ion concentrations $\left(\mathrm{Ni}^{2+}, \mathrm{Co}^{2+}, \mathrm{Al}^{3+}\right)$ were analyzed using Atomic Absorption Spectroscopy (PinAAcle 900T Perkin Elmer, Waltham, MA, USA).

The electrochemical performance was tested using a cylindrical cell (type 18650). The anode, separator, and electrolyte were composed of graphite, celgard, and $\mathrm{LiPF}_{6}$, respectively. To fabricate the cathode sheet, the RNCA material (active material) was mixed with a conductive agent (acetylene black/AB, MTI, Richmond, CA, USA) and a binder (polyvinylidene difluoride/PVDF, MTI, USA) in solvent (N-methyl-2-pyrrolidone/NMP, MTI, USA) to an RNCA/AB/PVDF mass ratio of 92:3:5. The homogeneous slurry was then coated via a doctor's blade technique onto Al foil to a thickness of $200 \mu \mathrm{m}$. The cathode sheet was dried in a vacuum oven at $80{ }^{\circ} \mathrm{C}$ overnight until it was ready for assembly in a glovebox. For comparison, fresh NCA powder purchased from BTR (China) was assembled and tested in a cylindrical cell (labelled Commercial NCA/Com-NCA). The electrode fabrication process for the anode sheet (graphite, MTI, America) was the same as that for the cathode. The ratio of the capacity of the cathode and the anode was 1:1.15. The full cell performance was analyzed using NEWARE Battery analyzer and BTS software.

\section{Results and Discussion}

\subsection{Pretreatment}

A pretreatment process which used $\mathrm{NaOH}$ dissolution to dissolve $\mathrm{Al}$ foil was employed to separate the powder from the Al foil. In order to eliminate PVDF (binder) and acetylene black (conductive agent), the obtained powder was heated to $800{ }^{\circ} \mathrm{C}$. In this experiment, the powder was processed at $800{ }^{\circ} \mathrm{C}$ at various heating times of 2 and $4 \mathrm{~h}$ (the samples were denoted P-01 and P-02). After heating at $800^{\circ} \mathrm{C}$, the PVDF and $\mathrm{AB}$ were assumed to be burned according to the findings of previous studies [7,47,48], which is beneficial for the leaching process [28].

A previous study reported that $\mathrm{CO}_{2}$ gas was formed during the heat treatment process. This occurrence was caused by the redox reaction between acetylene black $(A B)$ and the cathode material 
during which the transition metals were reduced from a high charge to a low charge [49]. For NCA material, the oxidation states of the transition metals are trivalent $\left(\mathrm{Li}^{+}, \mathrm{M}^{3+}, \mathrm{O}^{4-}\right)$. When the reduction reaction occurs, the state of the transition metals changes from trivalent to a divalent state. To verify the redox reaction and the effect of heat treatment on the NCA structure, the collected powders (P-01 and P-02) were analyzed using XRD.

The XRD patterns of the P-01 and P-02 samples compared to the sample before heating (denoted B-HT) can be seen in Figure 2. Based on a structural analysis, the XRD pattern indicates a hexagonal layered material which is similar to commercial NCA. However, the split peaks of $\mathrm{I}_{006} / \mathrm{I}_{012}$ and $\mathrm{I}_{018} / \mathrm{I}_{110}$ on P-01 and P-02 were merged into a single peak. This occurance can be caused by hydrofluoric acid (HF)released from decomposition of PVDF (binder) which attack the NCA material at a high temperature and lead to form lithium fluoride (LiF) [50]. According to previous studies, the merged peaks show the destruction of the layered structure of the material [51].

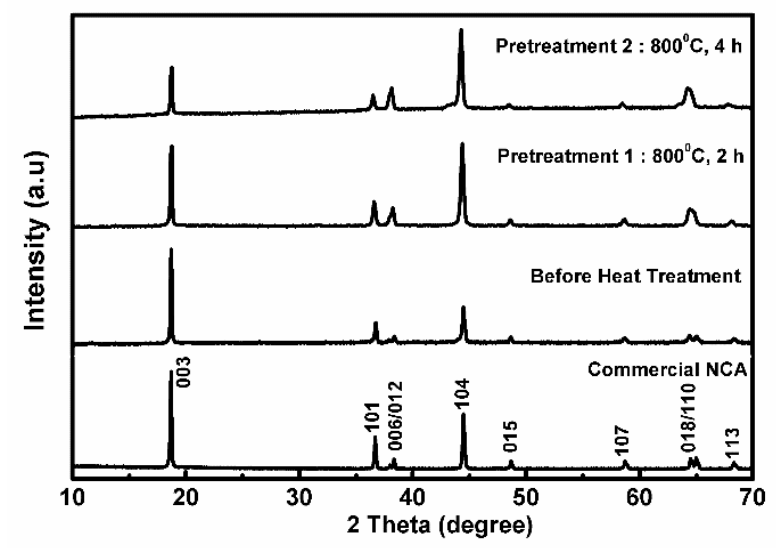

Figure 2. XRD pattern of NCA powder before heat treatment (B-HT) and after heat treatment at $800{ }^{\circ} \mathrm{C}$ for 2 or $4 \mathrm{~h}$ (P-01 and P-02 samples).

In addition, there is a change in the peak intensity of $\mathrm{I}_{003}$ and $\mathrm{I}_{004}$ after heat treatment in all samples. In this experiment, the intensity ratios of $\mathrm{I}_{003} / \mathrm{I}_{004}$ for P-01 and P-02 were 1.0112 and 0.644 . Yang et al. reported that the reduction of metals can be evaluated by the value of the intensity ratio of $\mathrm{I}_{003} / \mathrm{I}_{104}$ [49]. The acetylene black contained in the powder acts as a reducing agent [52] which promotes the reduction reaction of the transition metals in NCA during heat treatment [49]. From XRD analysis, it is predicted that higher reduction of metals occurred in the P-02 sample than in the P-01 sample; this in turn predicted more inactive divalent nickel compounds ( $\mathrm{NiO})$ of metals in the P-02 sample which can better facilitate the leaching process [49]. Therefore, this work used pretreatment conditions at $800{ }^{\circ} \mathrm{C}$ and a $4 \mathrm{~h}$ heating time for the next process.

Before any further treatments, we tested the performance of the B-HT and P-02 samples as the cathode and graphite as the anode in a cylindrical battery (full cell). The charge-discharge curve is presented in Figure 3 with voltage range of 2.7-4.2 V. The first cycle was used for formation, and the coulombic efficiencies of B-HT and P-02 were 34.3\% and 31.5\%. The specific discharge capacities of B-HT and P-02 were too low compared to the theoretical capacity of NCA (200 mAh/g) - 46.7 and $41.1 \mathrm{mAh} / \mathrm{g}$ at $4 \mathrm{~mA} / \mathrm{g}$, respectively. The P-02 capacity result corresponds to the XRD analysis which showed deterioration of the NCA structure after heat treatment. Although the XRD pattern of B-HT is quite good, it has poor specific capacity in battery performance. This may be caused by the washing effect of NCA after $\mathrm{NaOH}$ dissolution which leads to a reaction between NCA and water that forms nickel hydroxide and nickel oxide hydroxide on the NCA surface. The presence of nickel hydroxide and nickel oxide hydroxide on B-HT powder can affect the electrochemical properties and can block $\mathrm{Li}^{+}$diffusion during de-lithiation/lithiation [53]. Also, the PVDF and AB on the B-HT samples act as inactive materials which can reduce the specific capacity $(\mathrm{mAh} / \mathrm{g})$. Therefore, such further treatment is necessary to enhance the electrochemical performance of NCA. In this work, acid leaching and mixed 
metal hydroxide co-precipitation were applied as further processing to the P-02 sample in order to recover valuable metals and resynthesize NCA material.

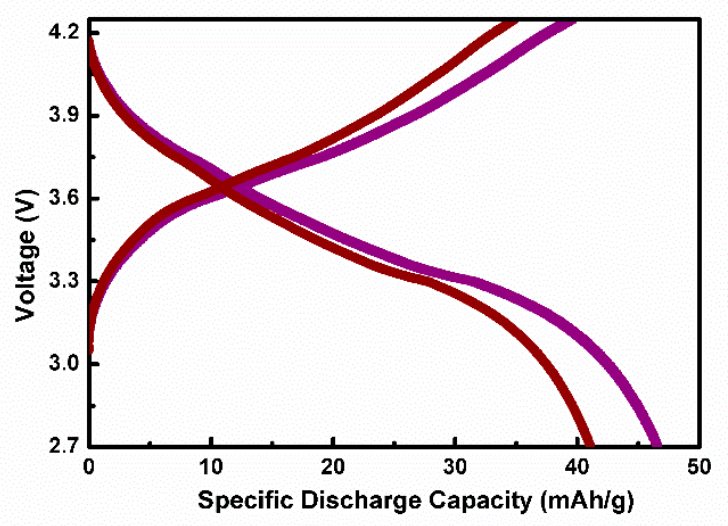

Figure 3. Specific Discharge Capacity (mAh/g) of the B-HT and P-02 Samples.

\subsection{Leaching Process}

In order to determine the most efficient leaching process for metal ions, various strong acids $(\mathrm{HCl}$, $\mathrm{H}_{2} \mathrm{SO}_{4}, \mathrm{HNO}_{3}$ ) were tested as leaching agents operating at an acid concentration of $4 \mathrm{M}$, temperature of $80{ }^{\circ} \mathrm{C}$, and leaching time of $60 \mathrm{~min}$. Also, metal ion extraction over time (2.5-60 min) was observed.

Figure 4 . shows the effect of various acids on the leaching efficiency for the P-02 sample at concentrations of $4 \mathrm{M}$ by heating at $80^{\circ} \mathrm{C}$ for $1 \mathrm{~h}$. In the present study, $\mathrm{HCl}$ shows the highest rates of leaching efficiency for $\mathrm{Ni}$ and $\mathrm{Co}$ in this experiment, which agrees with the results of a previous study [21]. Clearly, $\mathrm{HCl}$ is more suitable for the leaching of metal ions from NCA material as it achieved a rate of leaching efficiency that surpassed $95 \%$ for all metal ions. The great performance of $\mathrm{HCl}$ in the leaching process was due to the $\mathrm{Cl}^{-}$ions in $\mathrm{HCl}$; these showed high reactivity towards metals, resulting in a rapid attack on the metals [21,22].

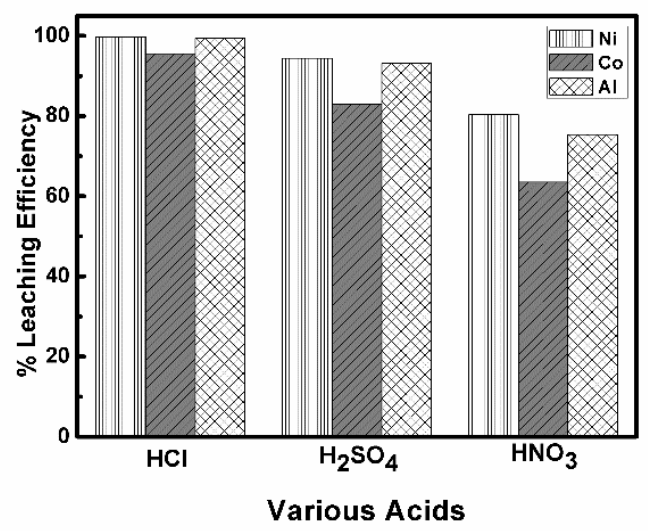

Figure 4. The effect of various acids on the leaching efficiency of NCA scrap $\left(4 \mathrm{M}, 80^{\circ} \mathrm{C}, 1 \mathrm{~h}\right)$.

Table 1 shows a summary of the leaching conditions used in metal recovery from $\mathrm{NCA}$ using $\mathrm{HCl}$ in previous works compared to this work. Based on the listed data, the leaching process in this work obtained high-efficiency metal recovery with a short leaching processing time and the absence of a reducing agent in spite of a high solid loading rate. Such phenomena may be caused by the reduction of ion metals during the pretreatment process which simplifies the leaching process. 
Table 1. Summary of leaching conditions used in metal recovery from NCA using $\mathrm{HCl}$ from previous works and the present work.

\begin{tabular}{|c|c|c|c|c|c|c|c|}
\hline $\begin{array}{c}\text { Material } \\
\text { Sources }\end{array}$ & $\begin{array}{l}\text { Leaching } \\
\text { Agent }\end{array}$ & $\begin{array}{l}\text { Solid to Liquid } \\
\text { (S/L) Ratio (g/L) }\end{array}$ & $\begin{array}{c}\text { Temperature } \\
\left({ }^{\circ} \mathrm{C}\right)\end{array}$ & $\begin{array}{c}\text { Time } \\
\text { (h) }\end{array}$ & $\begin{array}{c}\text { Reducing } \\
\text { Agent }\end{array}$ & Efficiency & Reference \\
\hline $\begin{array}{l}\text { Commercial } \\
\text { NCA }\end{array}$ & $4 \mathrm{M} \mathrm{HCl}$ & 50 & 90 & 18 & - & $\begin{array}{c}\mathrm{Ni}, \mathrm{Co}, \mathrm{Al}: \\
100 \%, \\
100 \% \\
100 \%\end{array}$ & [21] \\
\hline $\begin{array}{c}\text { Spent } \\
\text { NCA } \\
\text { Battery }\end{array}$ & $\begin{array}{c}\text { Concentrated } \\
\mathrm{HCl}\end{array}$ & - & - & - & - & - & [8] \\
\hline $\begin{array}{l}\text { NCA } \\
\text { Scrap }\end{array}$ & $4 \mathrm{M} \mathrm{HCl}$ & 100 & 80 & 1 & - & $\begin{array}{c}\mathrm{Ni}, \mathrm{Co}, \mathrm{Al}: \\
99.8 \% \\
95.6 \% \\
99.5 \%\end{array}$ & This work \\
\hline
\end{tabular}

In order to ensure that the pretreatment process with heating produces high-efficiency metal extractions, Figure 5 shows a comparison of $\mathrm{HCl}$ leaching at an acid concentration of $4 \mathrm{M}$, temperature of $80^{\circ} \mathrm{C}$, and leaching time of $60 \mathrm{~min}$ using the P-02 sample (after pretreatment with heating), B-HT (after pretreatment without heating), and commercial NCA. The results show that the leaching efficiencies of $\mathrm{Ni}, \mathrm{Co}$, and $\mathrm{Al}$ in $\mathrm{B}-\mathrm{HT}$ were the lowest compared to $\mathrm{P}-02$ and commercial NCA. The presence of PVDF and $\mathrm{AB}$ contained in B-HT may also be the reason for the poor leaching efficiency by inhibiting the diffusion of metals into solution. Therefore, the pretreatment process with heating provides a significant improvement in the leaching behavior of valuable metals under such conditions, e.g., high solid loading rate, short processing time, and absence of a reducing agent.

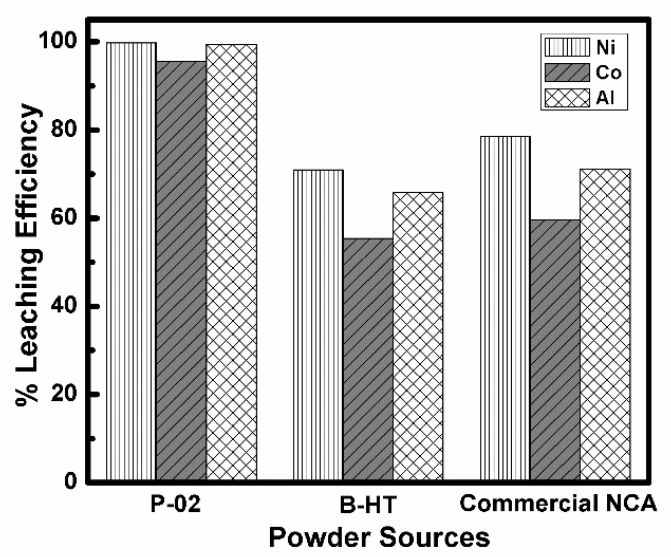

Figure 5. Comparison of leaching between P-02, B-HT, and commercial NCA $\left(4 \mathrm{M} \mathrm{HCl}, 80{ }^{\circ} \mathrm{C}, 1 \mathrm{~h}\right)$.

The leaching behavior using various leaching agents is shown in Figure 6 and is similar for all metals. The metals showed their highest leaching rates in the first $15 \mathrm{~min}$ of the leaching process, after which the leaching rate began to decelerate. The acid consumption during the beginning of leaching and the increasing metal ion concentrations increasing the viscosity of the medium are the main reasons for such occurrences. 

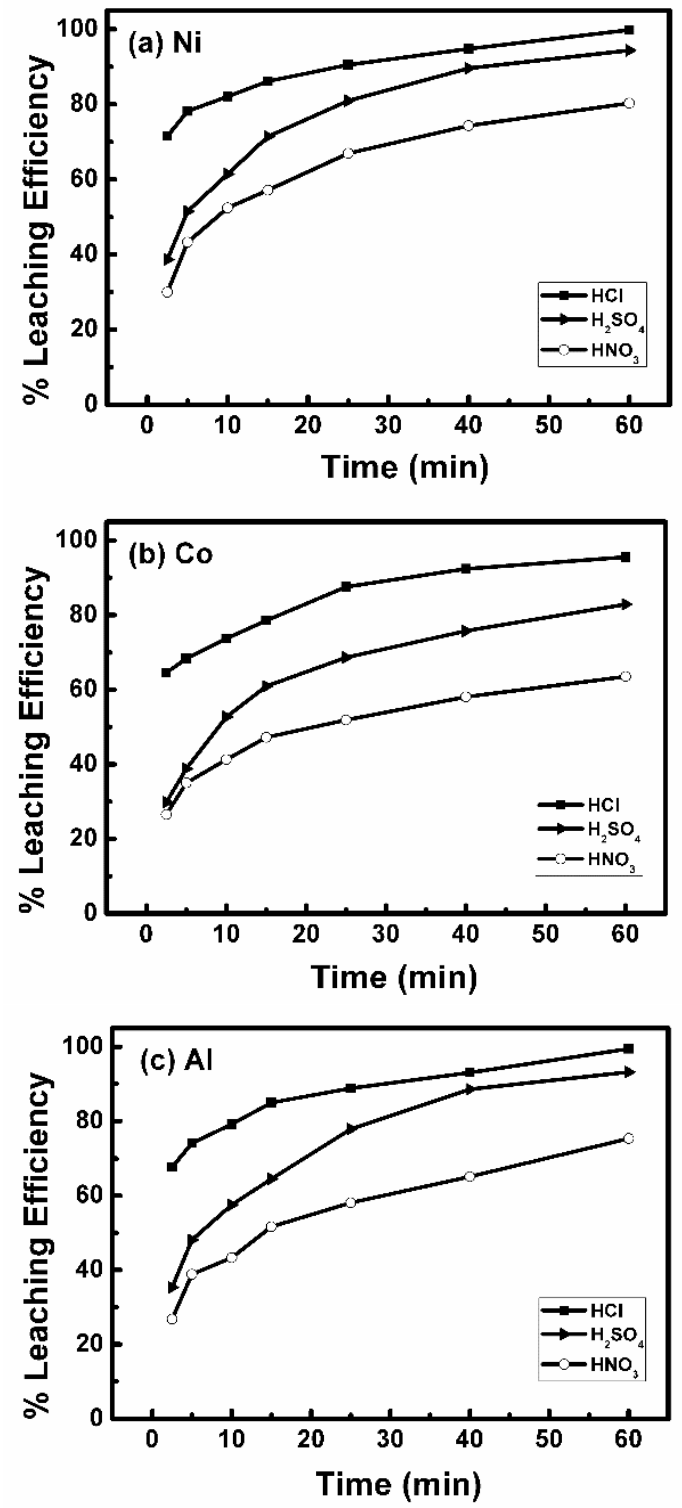

Figure 6. Leaching behavior using various acids during $60 \mathrm{~min}$ of processing $\left(4 \mathrm{M}, 80^{\circ} \mathrm{C}\right)$ : (a) Nickel; (b) Cobalt; (c) Aluminum.

Based on the results of the leaching efficiency, Co showed a lower efficiency of extraction during leaching than either $\mathrm{Ni}$ or $\mathrm{Al}$. $\mathrm{Ni}$ and Co were confirmed as residing in a trivalent state within the NCA material. $\mathrm{Ni}^{2+}$ is the stable state of $\mathrm{Ni}$ metals, so metal extraction from $\mathrm{Ni}^{3+}$ into $\mathrm{Ni}^{2+}$ is easy. The reactions between $\mathrm{Al}$ and strong acids are slow at room temperature, but the leaching reaction became both faster and easier when heat was applied. Because $\mathrm{Co}$ is in a stable state at $\mathrm{Co}^{3+}$, extraction from $\mathrm{Co}^{3+}$ to $\mathrm{Co}^{2+}$ was difficult, causing the leaching reaction to be slow $[28,54]$. The reaction during the leaching process is explained in Equations (2)-(4). When the metal oxides react with acids, the state of transition metals will change into a lower state $[30,54]$. Therefore, in this study, the reduction process of NCA leaching occurred in order to dissolve the metals into solution.

$$
\begin{aligned}
& 3 \mathrm{HCl}_{(\mathrm{aq})}+\mathrm{LiNi}_{0.80} \mathrm{Co}_{0.15} \mathrm{Al}_{0.05} \mathrm{O}_{2(\mathrm{~s})} \rightleftarrows \mathrm{LiCl}_{(\mathrm{aq})}+0.8 \mathrm{NiCl}_{2(\mathrm{aq})}+0.15 \mathrm{CoCl}_{2(\mathrm{aq})}+0.05 \mathrm{AlCl}_{3(\mathrm{aq})}+1.5 \mathrm{H}_{2} \mathrm{O}_{(\mathrm{liq})}+0.5 \mathrm{O}_{2(\mathrm{~g})} \\
& 3 \mathrm{H}_{2} \mathrm{SO}_{4(\mathrm{aq})}+2 \mathrm{LiNi}_{0.80} \mathrm{Co}_{0.15} \mathrm{Al}_{0.05} \mathrm{O}_{2(\mathrm{~s})} \rightleftarrows \mathrm{Li}_{2} \mathrm{SO}_{4(\mathrm{aq})}+1.6 \mathrm{NiSO}_{4(\mathrm{aq})}+0.3 \mathrm{CoSO}_{4(\mathrm{aq})}+0.05 \mathrm{Al}_{2}\left(\mathrm{SO}_{4}\right)_{3(\mathrm{aq})}+3 \mathrm{H}_{2} \mathrm{O}_{(\mathrm{liq})}+0.5 \mathrm{O}_{2(\mathrm{~g})} \\
& 3 \mathrm{HNO}_{3(\mathrm{aq})}+\mathrm{LiNi}_{0.80} \mathrm{Co}_{0.15} \mathrm{Al}_{0.05} \mathrm{O}_{2(\mathrm{~s})} \rightleftarrows \mathrm{LiNO}_{3(\mathrm{aq})}+0.8 \mathrm{Ni}\left(\mathrm{NO}_{3}\right)_{2(\mathrm{aq})}+0.15 \mathrm{Co}\left(\mathrm{NO}_{3}\right)_{2(\mathrm{aq})}+0.05 \mathrm{Al}\left(\mathrm{NO}_{3}\right)_{3(\mathrm{aq})}+1.5 \mathrm{H}_{2} \mathrm{O}_{(\mathrm{liq})}+0.5 \mathrm{O}_{2(\mathrm{~g})}
\end{aligned}
$$




\subsection{Characterization and Electrochemical Testing of Recycled NCA material}

\subsubsection{Functional Group Analysis of the -OH Precursor}

After the leaching process, the filtrate was precipitated using ammonia and $\mathrm{NaOH}$ as the monodentate ligand and precipitant agent, respectively. The greenish $-\mathrm{OH}$ precursors from the leachates of $\mathrm{HCl}, \mathrm{HNO}_{3}$, and $\mathrm{H}_{2} \mathrm{SO}_{4}$ were obtained and denoted P-HA, P-NA, and P-SA. The functional groups of the $-\mathrm{OH}$ precursor were identified using Fourier Transformed Infrared Spectroscopy (FT-IR), shown in Figure 7. These results are in agreement with those of previous research on $\mathrm{Ni}(\mathrm{OH})_{2}$ nanoplates $[55,56]$.

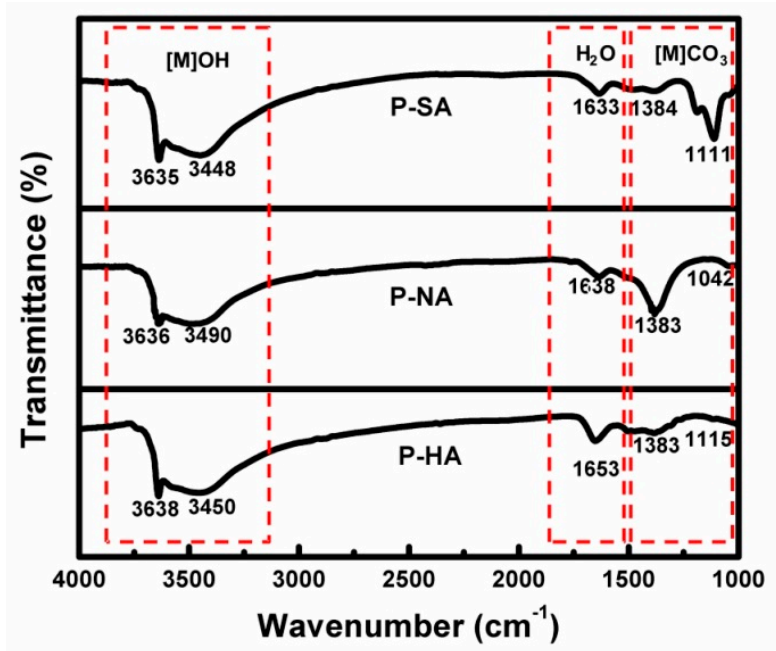

Figure 7. FT-IR analysis of the $-\mathrm{OH}$ precursor from the leachates of $\mathrm{H}_{2} \mathrm{SO}_{4}, \mathrm{HNO}_{3}$, and $\mathrm{HCl}$; denoted as P-SA, P-NA, P-HA (M: metal).

The sharp peak at approximately $3630 \mathrm{~cm}^{-1}$ indicates the stretched bond of $\mathrm{O}-\mathrm{H}$ (disturbed hydroxyl) from the free $\mathrm{Ni}-\mathrm{OH}$ groups. The band at approximately $3450 \mathrm{~cm}^{-1}$ is characteristic of $\mathrm{Ni}(\mathrm{OH})_{2}$ and the vibrational mode of $\mathrm{OH}$ (free hydroxyl), while the peak at $1630 \mathrm{~cm}^{-1}$ is the vibrational mode of water molecules $(\mathrm{H}-\mathrm{O}-\mathrm{H})$. The presence of $\mathrm{CO}_{3}{ }^{2-}$ was detected at approximately 1380 and $1100 \mathrm{~cm}^{-1}$. This may be caused by an interaction between $\mathrm{Ni}(\mathrm{OH})_{2}$ and $\mathrm{CO}_{2}$ under an air atmosphere during the storing of $-\mathrm{OH}$ precursors, which implies that the $-\mathrm{OH}$ precursor still contained slight amounts of $\mathrm{CO}_{3}{ }^{2-}$ and $\mathrm{H}_{2} \mathrm{O}$. Based on FTIR, P-HA has the weakest band at around 1380 and $1100 \mathrm{~cm}^{-1}$, indicate a slight amount of $\mathrm{CO}_{3}{ }^{2-}$ ions. These conditions may be caused by a small amount of residual product $(\mathrm{NaCl})$ remaining in the $-\mathrm{OH}$ precursor (P-HA) from the co-precipitation process which could inhibit the interaction between $\mathrm{Ni}(\mathrm{OH})_{2}$ and $\mathrm{CO}_{2}$ [57]. The reactions during the leaching process using $\mathrm{HCl}$ and mixed metal hydroxide co-precipitation are explained in Equations (5)-(7), where $\mathrm{MO}_{2}$ is a metal oxide. Hence, from FTIR analysis, it was found that P-HA is more resistant towards $\mathrm{CO}_{2}$ than P-SA and P-NA.

$$
\begin{gathered}
4 \mathrm{HCl}_{(\mathrm{aq})}+\mathrm{MO}_{2(\mathrm{~s})} \rightleftarrows \mathrm{MCl}_{2(\mathrm{aq})}+2 \mathrm{H}_{2} \mathrm{O}_{(\mathrm{liq})}+\mathrm{Cl}_{2(\mathrm{~g})} \\
\mathrm{MCl}_{2(\mathrm{aq})}+2 \mathrm{H}_{2} \mathrm{O}_{(\text {liq })}+\mathrm{NH}_{3(\mathrm{aq})} \rightleftarrows \mathrm{M}\left(\mathrm{NH}_{3}\right)^{2+}{ }_{(\mathrm{aq})}+2 \mathrm{Cl}^{-}{ }_{(\mathrm{aq})}+2 \mathrm{H}_{2} \mathrm{O}_{(\text {liq })} \\
\mathrm{M}\left(\mathrm{NH}_{3}\right)^{2+}{ }_{(\mathrm{aq})}+2 \mathrm{Cl}^{-}{ }_{(\mathrm{aq})}+2 \mathrm{H}_{2} \mathrm{O}_{(\text {liq })}+2 \mathrm{NaOH}_{(\mathrm{aq})} \rightleftarrows \mathrm{M}(\mathrm{OH})_{2}(\mathrm{~s})+2 \mathrm{NaCl}_{(\mathrm{aq})}+\mathrm{NH}_{3(\mathrm{aq})}+2 \mathrm{H}_{2} \mathrm{O}_{(\text {liq })}
\end{gathered}
$$

\subsubsection{Structure Analysis of Recycled NCA}

Next, the -OH precursors (P-HA, P-NA, P-SA) were processed to resynthesize NCA material which was mixed with $\mathrm{LiOH}$ ( $\mathrm{mol}$ ratio $=1: 1.03$ ) and then calcined and sintered in a muffle furnace in order to obtain Recycled NCA material (denoted RNCA). The obtained RNCA types from various forms of -OH precursors (P-HA, P-NA, P-SA) were denoted RNCA-HA, RNCA-NA, and RNCA-SA. 
The structures of RNCA were characterized using XRD. Figure 8 shows the XRD patterns of RNCA-HA, RNCA-NA, and RNCA-NA, which revealed that all samples are similar and a good fit to JCPDS \#87-1562. These results show that the RNCA crystal phase is $\alpha-\mathrm{NaFeO}_{2}$ with a $\mathrm{R} 3 \mathrm{~m}$ space group. The explicit splits at $\mathrm{I}_{006} / \mathrm{I}_{012}$ and $\mathrm{I}_{018} / \mathrm{I}_{110}$ indicate the favorable hexagonal layered structure of RNCA.

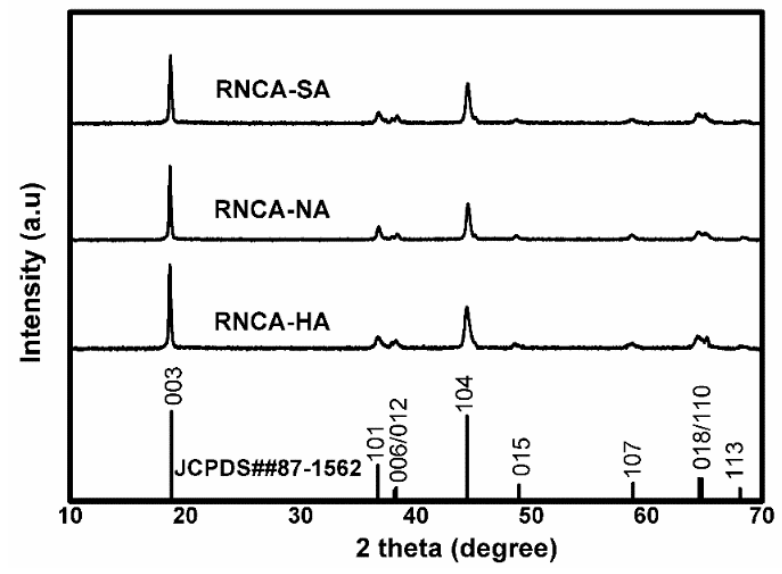

Figure 8. XRD patterns of RNCA using different leaching agents.

The calculation of the lattice parameters from the XRD patterns is presented in Table 2. The lattice parameters show similar results for all samples. The values of c, a, and c/a from the RNCA samples are in accordance with those of NCA material from previous research on NCA synthesis $[44,55,58,59]$. The intensity ratio of the $\mathrm{I}_{003} / \mathrm{I}_{104}$ peak identifies the degree of cation mixing in the NCA structures. Cation mixing is a phenomenon caused by the presence of $\mathrm{Ni}^{2+}$ ions in $\mathrm{Li}^{+}$and $\mathrm{Ni}^{3+}$ lattices due to the similarity of their ionic size [51]. A higher intensity ratio of the $\mathrm{I}_{003} / \mathrm{I}_{104}$ peak results in lower levels of undesired cation disorder. Based on Table 2, all samples have $\mathrm{I}_{003} / \mathrm{I}_{004}$ greater than 1.2, indicating a low degree of cation mixing $[44,55,59,60]$. The ratio of c/a represents the degree of crystallinity and stability of the RNCA material $[59,61]$. RNCA-HA had the highest c/a ratio in the present study, implied high crystallinity of the material. This was probably due to the small amounts of residual product $(\mathrm{NaCl})$ remaining in the P-HA sample after the co-precipitation process (see Equations (2)-(4)), influencing crystal formation during the sintering process. The previous research showed that the presence of salt $(\mathrm{NaCl})$ could increase the crystallinity of the material [46], resulting in a better predicted charge-discharge performance [62].

Table 2. Lattice parameters of RNCA.

\begin{tabular}{cccccc}
\hline \multirow{2}{*}{ Samples } & \multicolumn{2}{c}{ Lattice Parameters } & \multirow{2}{*}{$\mathbf{c} / \mathbf{a}$} & \multirow{2}{*}{$\mathbf{I}_{\mathbf{0 0 3}} / \mathbf{I}_{\mathbf{1 0 4}}$} & \multirow{2}{*}{$\mathbf{V}\left(\AA^{3}\right)$} \\
\cline { 2 - 3 } & $\mathbf{a}(\AA)$ & $\mathbf{c}(\AA)$ & & & \\
\hline RNCA-HA & 2.8692 & 14.2857 & 4.9789 & 1.6102 & 101.8506 \\
RNCA-NA & 2.8630 & 14.2134 & 4.9645 & 1.7003 & 100.8947 \\
RNCA-SA & 2.8629 & 14.2278 & 4.9697 & 1.4458 & 100.9885 \\
\hline
\end{tabular}

In order to calculate the values of the crystallite sizes of RNCA samples, the Debye-Scherrer Equation was used (Equation (5)), where $D_{\mathrm{p}}$ is the average crystallite size, $\lambda$ is the X-ray wavelength $(1.54178 \AA), \mathrm{k}$ is the Scherrer constant (0.9 1), B is the FWHM (Full Width at Half-Maximum) of the XRD peak, and $\theta$ is the XRD peak position.

$$
D p=\frac{\mathrm{k} \lambda}{B \cos \theta}
$$


Figure 9 presents the crystallite size of all RNCA samples. From the figure, it can be seen that the crystallite sizes of RNCA-HA, RNCA-NA, and RNCA-SA were 23.27, 29.04, and $28.87 \mathrm{~nm}$, respectively. It can be concluded that all of the RNCA samples had a small crystallite size.

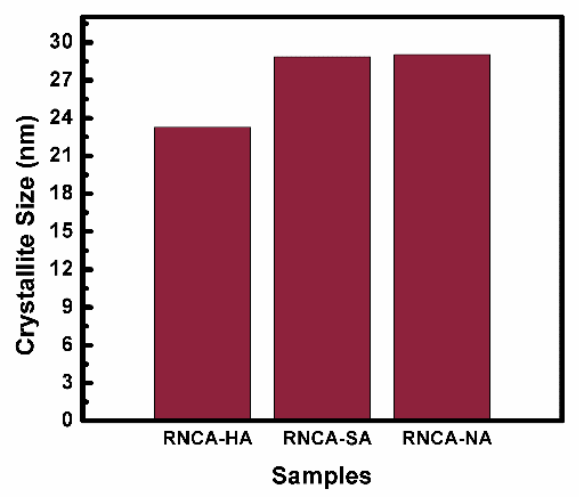

Figure 9. Crystallite sizes of RNCA Samples.

The morphology of the RNCA samples was studied using SEM. The SEM images in Figure 10 show the morphology of all RNCA material at 1000× and 5000 $\times$ magnifications. All RNCA material shows a sphere-like morphology and micro-sized secondary particles consisting of submicron primary particles. The average diameter of the primary particles is approximately $311 \sim 353 \mathrm{~nm}$. However, the morphologies of the particles are heterogeneous and large amounts of aggregates are formed. This may be caused by the difficult precipitation of $\mathrm{Al}(\mathrm{OH})_{3}$, which is confirmed by the $\mathrm{K}_{\mathrm{sp}}$ data. This situation could inhibit the particle growth and spherical particle formation $[58,63]$ which is responsible for the formation of aggregates.

\subsubsection{Electrochemical Performance of Recycled NCA}

After the RNCA materials were completely synthesized, for commercial applications, the final products of RNCA were tested using a full cell (18650-type of cylindrical battery) using graphite, celgard, and $\mathrm{LiPF}_{6}$ as the anode, separator, and electrolyte, respectively; this cell was then analyzed using a NEWARE Battery analyzer and BTS software. Figure 11 shows the charge-discharge capacity of the RNCA material for voltages ranging from 2.7 to $4.2 \mathrm{~V}$ at $4 \mathrm{~mA} / \mathrm{g}$. The first cycles of the RNCA batteries were used for formation, and the coulombic efficiencies of the first cycle were $71.2 \%$ (Commercial NCA), 69.7\% (RNCA-HA), 68.6\% (RNCA-NA), and 68.2\% (RNCA-SA). According to a previous study, the loss of discharge capacity in the first cycle may be caused by a local defect in the interlayer space during the de-lithiation process involving the oxidation of $\mathrm{Ni}^{2+}$ to $\mathrm{Ni}^{3+}$ in the $3 \mathrm{a}$ Li site and resulting in a capacity loss during the lithiation process [64]. However, the values of the coulombic efficiencies of RNCA samples in the first cycle are insignificantly different when compared to that of commercial NCA. 


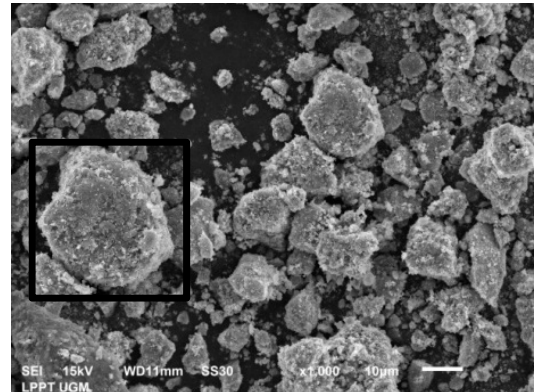

(a)

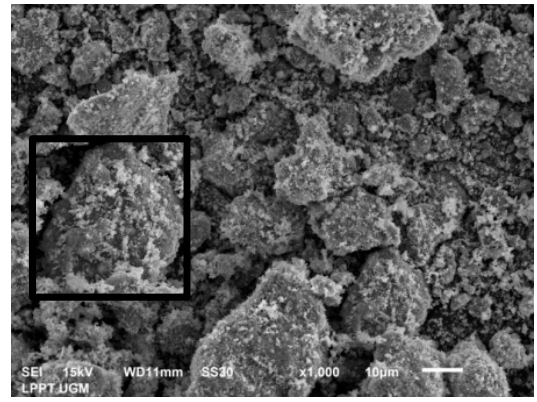

(c)

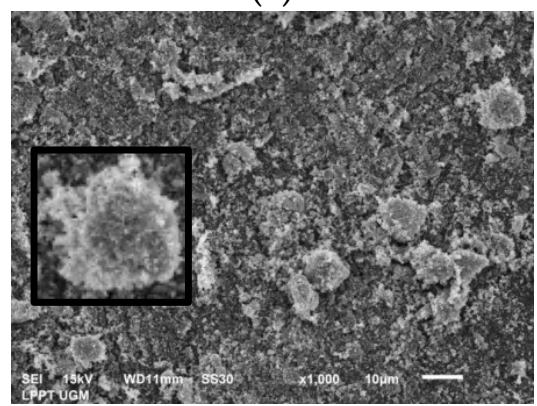

(e)

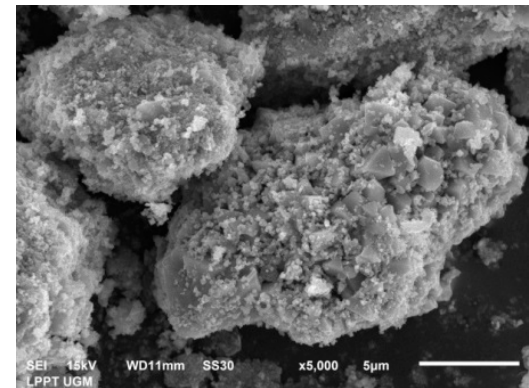

(b)

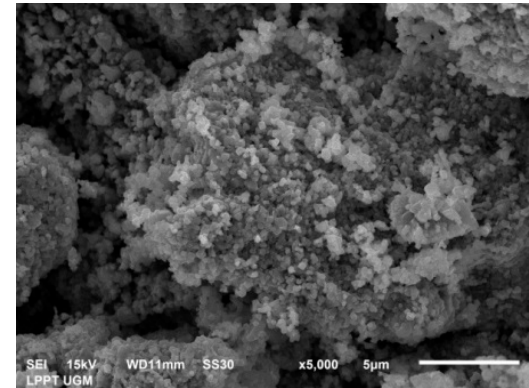

(d)

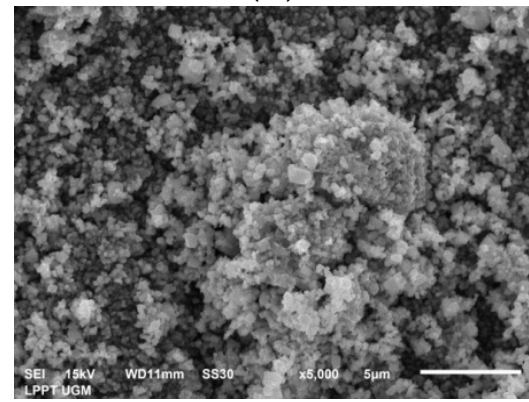

(f)

Figure 10. SEM images of RNCA material: (a,b) RNCA-HA; (c,d) RNCA-NA; (e,f) RNCA-SA.

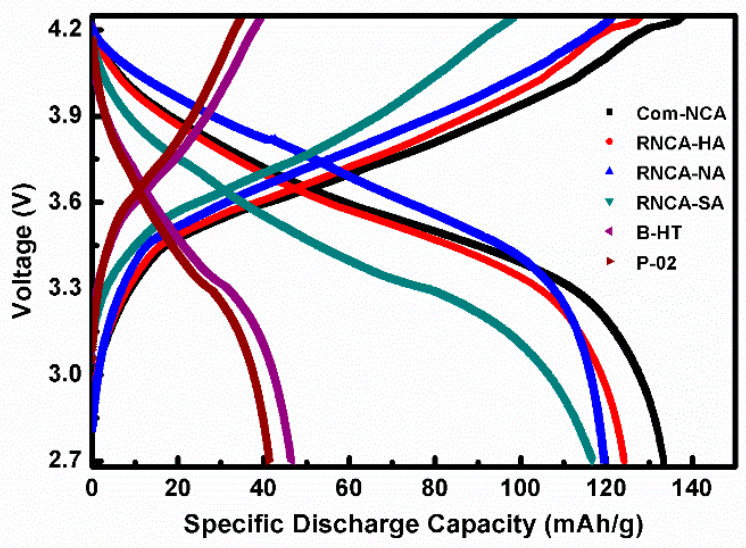

Figure 11. Specific Discharge Capacity of all RNCA samples at $0.02 \mathrm{C}$.

From the charge-discharge curve at $4 \mathrm{~mA} / \mathrm{g}$, the discharge capacities of Commercial NCA, RNCA-HA, RNCA-NA, and RNCA-SA are 133.40, 124.156, 119.570, and $116.567 \mathrm{mAh} / \mathrm{g}$, respectively; the values for recycled NCA are slightly different to that of commercial NCA. The highest specific discharge capacity measured in the present study was obtained by RNCA-HA. This result corresponds 
to the XRD pattern of RNCA-HA which has the highest crystallinity, and this confirms that high crystallinity has a strong impact on the discharge capacity [59,62]. Compared with the P-02 and B-HT samples, resynthesis of RNCA via the hydrometallurgical route delivered better discharge capacities that were improved by more than $150 \%$ over that of heat treatment.

The results of ratability and cyclability tests on the RNCA-HA and commercial NCA are displayed in Figure 12. Ratability or rate performance was assessed by charging and discharging the battery cells at various rates. In this study, the battery cells were charged and discharged at 4, 20, 40, 100, and $200 \mathrm{~mA} / \mathrm{g}$. From the data in Figure 11, the results show that the specific capacities of RNCA-HA and Commercial NCA have similar ratability behaviors. The specific capacities of both samples slightly decrease from 4 to $200 \mathrm{~mA} / \mathrm{g}$; the capacity retentions at various rates are presented in Table 3. The capacity drops of RNCA-HA and commercial NCA from 4 to $200 \mathrm{~mA} / \mathrm{g}$ are $27.4 \%$ and 25.2\%, which are only slightly different. From the data in Table 3, the RNCA-HA has a larger capacity drop than commercial NCA, which may be caused by the large amount of aggregation of primary particles that formed in RNCA-HA. Based on the SEM images, some primary particles did not agglomerate into larger secondary particles. Loose submicron primary particles have a larger surface area and are reactive with electrolytes during the charge-discharge process, which could lead to side reactions forming a passivation surface $[46,65,66]$ and cause a defect in the electrochemical performance. After being cycled at $200 \mathrm{~mA} / \mathrm{g}$, the cells were charged and discharged at $4 \mathrm{~mA} / \mathrm{g}$ five times to prove the reversibility of Li-ion insertion and de-insertion. A slight capacity drop was observed in each sample. Overall, each battery was stable or exhibited a small capacity decrease from the 4 to $200 \mathrm{~mA} / \mathrm{g}$. Also, RNCA-HA showed a higher retention of capacity (96\%) after 40 cycles at $100 \mathrm{~mA} / \mathrm{g}$ than commercial NCA $(93.4 \%)$ in a cycling test. It was confirmed that the high crystallinity of RNCA-HA influences the stability in electrochemical performance [59,62]. Both samples have high coulombic efficiencies of over $99 \%$. Clearly, the electrochemical performance of RNCA-HA is comparable with that of commercial NCA in full cell testing.
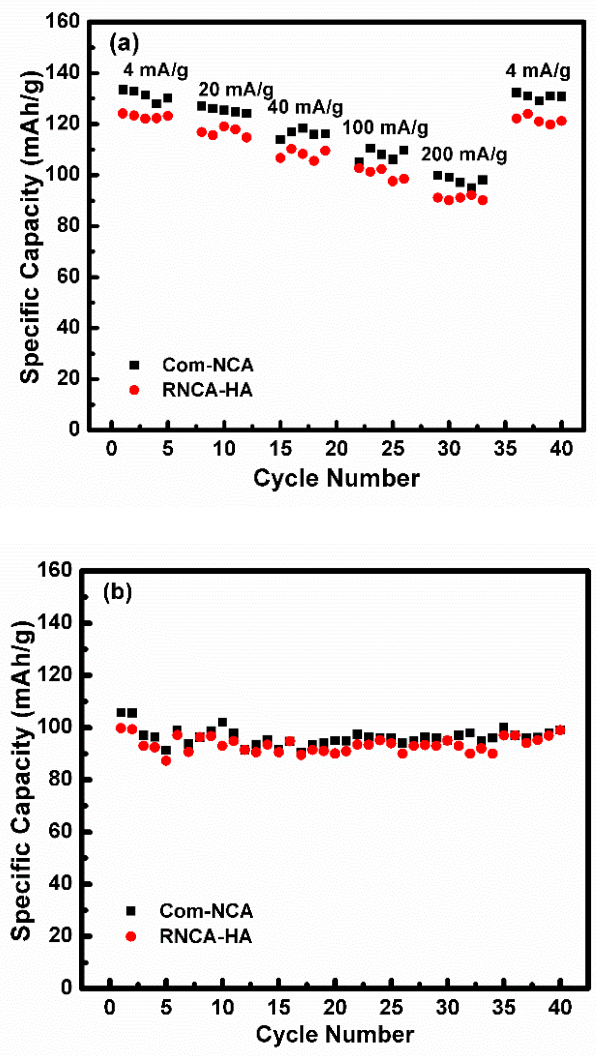

Figure 12. Performance test of RNCA-HA: (a) Ratability; (b) Cyclability at $100 \mathrm{~mA} / \mathrm{g}$. 
Table 3. Capacity retention of RNCA-HA and commercial NCA at various rate.

\begin{tabular}{|c|c|c|c|c|c|c|}
\hline \multirow{2}{*}{ Samples } & \multicolumn{6}{|c|}{ Capacity Retention (\%) } \\
\hline & $4 \mathrm{~mA} / \mathrm{g}$ & $20 \mathrm{~mA} / \mathrm{g}$ & $40 \mathrm{~mA} / \mathrm{g}$ & $100 \mathrm{~mA} / \mathrm{g}$ & $200 \mathrm{~mA} / \mathrm{g}$ & $4 \mathrm{~mA} / \mathrm{g}$ \\
\hline RNCA-HA & 100 & 94.2 & 85.9 & 82.7 & 72.6 & 99.2 \\
\hline Commercial NCA & 100 & 95.2 & 86.2 & 82.4 & 74.8 & 99.2 \\
\hline
\end{tabular}

\section{Conclusions}

The regeneration of a sphere-like-shaped NCA material was successful using a fast process that involved leaching and mixed metal hydroxide co-precipitation. $\mathrm{HCl}, \mathrm{H}_{2} \mathrm{SO}_{4}$, and $\mathrm{HNO}_{3}$ were used as the leaching agents. The highest leaching efficiency occurred when using $\mathrm{HCl}$ with a high solid loading rate, short processing time, and absence of reducing agent; the metal efficiencies were $99.8 \%$ for $\mathrm{Ni}$, $95.6 \%$ for Co, and $99.5 \%$ for Al. The XRD patterns of all samples were similar and well indexed to JCPDS. SEM images showed loose submicron primary particles which influenced the electrochemical performance. RNCA-HA has the highest specific discharge capacity of $124.156 \mathrm{mAh} / \mathrm{g}$ with capacity retention of $95.988 \%$ after 40 cycles at $100 \mathrm{~mA} / \mathrm{g}$. Large amounts of aggregates on the morphology caused side reactions during the charge-discharge process, resulting in a slight defect on the ratability test. However, this approach is promising for adaptation to large-scale production considering the simple and efficient process for resynthesizing NCA material and that the performance is comparable with that of commercial NCA.

Author Contributions: Conceptualization, A.N., H.W., H.H., H.N. and F.F.; Data curation, S.U.M.; Formal analysis, S.U.M.; Investigation, C.S.Y., H.H., H.N. and F.F.; Methodology, S.U.M.; Project administration, A.P.; Supervision, A.P.; Validation, A.N. and H.W.; Visualization, C.S.Y.; Writing-original draft, S.U.M.; Writing-review and editing, A.P.

Funding: This research was funded by LPDP through the RISPRO Invitation Scheme (Contract number: PRJ-31/LPDP/2018) and the Ministry of Research, Technology and Higher Education (KemenRistekdikti) through the Penelitian Hibah Kompetensi scheme (Contract number: 474/UN27.21/PP/2018).

Acknowledgments: Soraya U. Muzayanha is thankful for the Master Program Scholarship provided by Sebelas Maret University.

Conflicts of Interest: There is no conflict of interest to declare.

\section{References}

1. Nitta, N.; Wu, F.; Lee, J.T.; Yushin, G. Li-ion battery materials: Present and future. Biochem. Pharmacol. 2015, 18, 252-264. [CrossRef]

2. Pillot, C. Lithium ion battery raw material Supply \& demand 2016-2025. In Proceedings of the Advanced Automotive Battery Conference, Mainz, Germany, 30 January 2017.

3. Lai, Y.; Xu, M.; Zhang, Z.; Gao, C.; Wang, P.; Yu, Z. Optimized structure stability and electrochemical

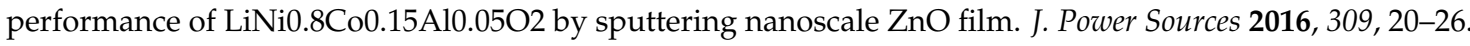
[CrossRef]

4. Zheng, X.; Zhu, Z.; Lin, X.; Zhang, Y.; He, Y.; Cao, H.; Sun, Z. A Mini-Review on Metal Recycling from Spent Lithium Ion Batteries. Engineering 2018, 4, 361-370. [CrossRef]

5. Shin, S.M.; Kim, N.H.; Sohn, J.S.; Yang, D.H.; Kim, Y.H. Development of a metal recovery process from Li-ion battery wastes. Hydrometallurgy 2005, 79, 172-181. [CrossRef]

6. Yang, L.; Xi, G.; Xi, Y. Recovery of Co, Mn, Ni, and Li from spent lithium ion batteries for the preparation of $\mathrm{LiNi}_{\mathrm{x}} \mathrm{Co}_{\mathrm{y}} \mathrm{Mn}_{\mathrm{z}} \mathrm{O}_{2}$ cathode materials. Ceram. Int. 2015, 41, 11498-11503. [CrossRef]

7. Li, L.; Chen, R.; Sun, F.; Wu, F.; Liu, J. Preparation of LiCoO2 films from spent lithium-ion batteries by a combined recycling process. Hydrometallurgy 2011, 108, 220-225. [CrossRef]

8. Sandhya, C.P.; John, B.; Gouri, C. Synthesis, characterization and electrochemical evaluation of mixed oxides of nickel and cobalt from spent lithium-ion cells. RSC Adv. 2016, 6, 114192-114197. [CrossRef]

9. Weng, Y.; Xu, S.; Huang, G.; Jiang, C. Synthesis and performance of Li[(Ni1/3Co1/3Mn1/3)1-xMgx $] \mathrm{O} 2$ prepared from spent lithium ion batteries. J. Hazard. Mater. 2013, 246-247, 163-172. [CrossRef] 
10. Chen, L.; Tang, X.; Zhang, Y.; Li, L.; Zeng, Z.; Zhang, Y. Process for the recovery of cobalt oxalate from spent lithium-ion batteries. Hydrometallurgy 2011, 108, 80-86. [CrossRef]

11. Ferreira, D.A.; Prados, L.M.Z.; Majuste, D.; Mansur, M.B. Hydrometallurgical separation of aluminium, cobalt, copper and lithium from spent Li-ion batteries. J. Power Sources 2009, 187, 238-246. [CrossRef]

12. Li, L.; Lu, J.; Ren, Y.; Zhang, X.X.; Chen, R.J.; Wu, F.; Amine, K. Ascorbic-acid-assisted recovery of cobalt and lithium from spent Li-ion batteries. J. Power Sources 2012, 218, 21-27. [CrossRef]

13. Li, J.; Shi, P.; Wang, Z.; Chen, Y.; Chang, C.C. A combined recovery process of metals in spent lithium-ion batteries. Chemosphere 2009, 77, 1132-1136. [CrossRef]

14. Chen, X.; Chen, Y.; Zhou, T.; Liu, D.; Hu, H.; Fan, S. Hydrometallurgical recovery of metal values from sulfuric acid leaching liquor of spent lithium-ion batteries. Waste Manag. 2015, 38, 349-356. [CrossRef] [PubMed]

15. Zhang, Z.; He, W.; Li, G.; Xia, J.; Hu, H.; Huang, J.; Zhang, S. Recovery of Lithium Cobalt Oxide Material from the Cathode of Spent Lithium-Ion Batteries. ECS Electrochem. Lett. 2014, 3, 58-61. [CrossRef]

16. Georgi-Maschler, T.; Friedrich, B.; Weyhe, R.; Heegn, H.; Rutz, M. Development of a recycling process for Li-ion batteries. J. Power Sources 2012, 207, 173-182. [CrossRef]

17. Itoh, H.; Miyanaga, H.; Kamiya, M.; Sasai, R. Recovery of rare metals from spent lithium ion cells by hydrothermal treatment and its technology assessment. Waste Manag. Environ. III 2006, 1, 3-12. [CrossRef]

18. Horeh, N.B.; Mousavi, S.M.; Shojaosadati, S.A. Bioleaching of valuable metals from spent lithium-ion mobile phone batteries using Aspergillus Niger. J. Power Sources 2016, 320, 257-266. [CrossRef]

19. Zeng, G.; Deng, X.; Luo, S.; Luo, X.; Zou, J. A copper-catalyzed bioleaching process for enhancement of cobalt dissolution from spent lithium-ion batteries. J. Hazard. Mater. 2012, 199-200, 164-169. [CrossRef] [PubMed]

20. Xin, B.; Zhang, D.; Zhang, X.; Xia, Y.; Wu, F.; Chen, S.; Li, L. Bioleaching mechanism of Co and Li from spent lithium-ion battery by the mixed culture of acidophilic sulfur-oxidizing and iron-oxidizing bacteria. Bioresour. Technol. 2009, 100, 6163-6169. [CrossRef]

21. Joulié, M.; Laucournet, R.; Billy, E. Hydrometallurgical process for the recovery of high value metals from spent lithium nickel cobalt aluminum oxide based lithium-ion batteries. J. Power Sources 2014, 247, 551-555. [CrossRef]

22. Takacova, Z.; Havlik, T.; Kukurugya, F.; Orac, D. Hydrometallurgy Cobalt and lithium recovery from active mass of spent Li-ion batteries: Theoretical and experimental approach. Hydrometallurgy 2016, 163, 9-17. [CrossRef]

23. Gratz, E.; Sa, Q.; Apelian, D.; Wang, Y. A closed loop process for recycling spent lithium ion batteries. J. Power Sources 2014, 262, 255-262. [CrossRef]

24. Meshram, P.; Pandey, B.D.; Mankhand, T.R.A.J.; Deveci, H. Comparision of Different Reductants in Leaching of Spent Lithium Ion Batteries. JOM 2016. [CrossRef]

25. Chen, X.; Zhou, T. Hydrometallurgical process for the recovery of metal values from spent lithium-ion batteries in citric acid media. Waste Manag. Res. 2014, 32, 1083-1093. [CrossRef]

26. Li, L.; Ge, J.; Chen, R.; Wu, F.; Chen, S.; Zhang, X. Environmental friendly leaching reagent for cobalt and lithium recovery from spent lithium-ion batteries. Waste Manag. 2010, 30, 2615-2621. [CrossRef]

27. Nayaka, G.P.; Manjanna, J.; Pai, K.V.; Vadavi, R.; Keny, S.J.; Tripathi, V.S. Recovery of valuable metal ions from the spent lithium-ion battery using aqueous mixture of mild organic acids as alternative to mineral acids. Hydrometallurgy 2015, 151, 73-77. [CrossRef]

28. Li, L.; Bian, Y.; Zhang, X.; Guan, Y.; Fan, E.; Wu, F.; Chen, R. Process for recycling mixed-cathode materials from spent lithium-ion batteries and kinetics of leaching. Waste Manag. 2018, 71, 362-371. [CrossRef]

29. Gao, W.; Liu, C.; Cao, H.; Zheng, X.; Lin, X.; Wang, H. Comprehensive evaluation on effective leaching of critical metals from spent lithium-ion batteries. Waste Manag. 2018. [CrossRef]

30. Kang, J.; Senanayake, G.; Sohn, J.; Shin, S.M. Recovery of cobalt sulfate from spent lithium ion batteries by reductive leaching and solvent extraction with Cyanex 272. Hydrometallurgy 2010, 100, 168-171. [CrossRef]

31. Wang, F.; Sun, R.; Xu, J.; Chen, Z.; Kang, M. Recovery of cobalt from spent lithium ion batteries using sulphuric acid leaching followed by solid-liquid separation and solvent extraction. R. Soc. Chem. 2016. [CrossRef]

32. Nguyen, V.T.; Lee, J.; Jeong, J.; Kim, B.; Pandey, B.D. Selective Recovery of Cobalt, Nickel and Lithium from Sulfate Leachate of Cathode Scrap of Li-ion Batteries Using Liquid-Liquid Extraction. Met. Mater. Int. 2014, 20, 357-365. [CrossRef] 
33. Jha, M.K.; Kumari, A.; Jha, A.K.; Kumar, V.; Hait, J.; Pandey, B.D. Recovery of lithium and cobalt from waste lithium ion batteries of mobile phone. Waste Manag. 2013, 33, 1890-1897. [CrossRef]

34. Lupi, C.; Pasquali, M.; Dell'Era, A. Nickel and cobalt recycling from lithium-ion batteries by electrochemical processes. Waste Manag. 2005, 25, 215-220. [CrossRef] [PubMed]

35. Myoung, J.; Jung, Y.; Lee, J.; Tak, Y. Cobalt oxide preparation from waste LiCoO2 by electrochemical-Hydrothermal method. J. Power Sources 2002, 112, 639-642. [CrossRef]

36. Prabaharan, G.; Barik, S.P.; Kumar, N.; Kumar, L. Electrochemical process for electrode material of spent lithium ion batteries. Waste Manag. 2017, 68, 527-533. [CrossRef] [PubMed]

37. Wang, R.C.; Lin, Y.C.; Wu, S.H. A novel recovery process of metal values from the cathode active materials of the lithium-ion secondary batteries. Hydrometallurgy 2009, 99, 194-201. [CrossRef]

38. Castillo, S.; Ansart, F.; Laberty-Robert, C.; Portal, J. Advances in the recovering of spent lithium battery compounds. J. Power Sources 2002, 112, 247-254. [CrossRef]

39. Chen, W.; Ho, H. Recovery of Valuable Metals from Lithium-Ion Batteries NMC Cathode Waste Materials by Hydrometallurgical Methods. Metals 2018, 8, 321. [CrossRef]

40. Korkmaz, K.; Alemrajabi, M.; Forsberg, K.M. Sustainable Hydrometallurgical Recovery of Valuable Elements from Spent Nickel-Metal Hydride HEV Batteries. Metals 2018, 8, 1062. [CrossRef]

41. Zou, H.; Gratz, E.; Apelian, D.; Wang, Y. A novel method to recycle mixed cathode materials for lithium ion batteries. Green Chem. 2013, 15, 1183-1191. [CrossRef]

42. Sandhya, C.P.; John, B.; Gouri, C. Lithium titanate as anode material for lithium-ion cells: A review. Ionics 2014, 601-620. [CrossRef]

43. Park, Y.M.; Lim, H.; Moon, J.-H.; Lee, H.-N.; Son, S.H.; Kim, H.; Kim, H.J. High-Yield One-Pot Recovery and Characterization of Nanostructured Cobalt Oxalate from Spent Lithium-Ion Batteries and Successive Re-Synthesis of LiCoO2. Metals 2017, 7, 303. [CrossRef]

44. Qiu, Z.; Zhang, Y.; Dong, P.; Xia, S.; Yao, Y. A facile method for synthesis of LiNi0.8Co0.15A10.05O2 cathode material. Solid State Ionics 2017, 307, 73-78. [CrossRef]

45. Chen, J.; Li, Q.; Song, J.; Song, D.; Zhang, L.; Shi, X. Environmentally friendly recycling and effective repairing of cathode powders from spent LiFePO4 batteries. Green Chem. 2016, 18, 2500-2506. [CrossRef]

46. Purwanto, A.; Yudha, C.S.; Ubaidillah, U.; Widiyandari, H.; Ogi, T. NCA cathode material: Synthesis methods and performance enhancement efforts NCA cathode material: Synthesis methods and performance enhancement efforts. Mater. Res. Express 2018, 5, 122001. [CrossRef]

47. Nie, H.; Xu, L.; Song, D.; Song, J.; Shi, X.; Wang, X.; Zhang, L.; Yuan, Z. LiCoO2: Recycling from spent batteries and regeneration with solid state synthesis. R. Soc. Chem. 2015, 17, 1276-1280. [CrossRef]

48. Lu, M.; Zhang, H.; Wang, B.; Zheng, X.; Dai, C. The re-synthesis of LiCoO2 from spent lithium ion batteries separated by vacuum-assisted heat-treating method. Int. J. Electrochem. Sci. 2013, 8, 8201-8209.

49. Yang, Y.; Huang, G.; Xu, S.; He, Y.; Liu, X. Thermal treatment process for the recovery of valuable metals from spent lithium-ion batteries. Hydrometallurgy 2015. [CrossRef]

50. Zhang, X.; Xue, Q.; Fan, E.; Wu, F.; Chen, R. Sustainable Recycling and Regeneration of Cathode Scraps from Industrial Production of Lithium-Ion Batteries. ACS Sustain. Chem. Eng. 2016. [CrossRef]

51. Kalyani, P.; Kalaiselvi, N. Various aspects of LiNiO2 chemistry: A review. Sci. Technol. Adv. Mater. 2005, 6, 689-703. [CrossRef]

52. Ma, S.; Lee, Y.; Ahn, K.; Kim, C.; Oh, K.; Kim, K. Spontaneously Deposited Manganese Oxide on Acetylene Black in an Aqueous Potassium Permanganate Solution. J. Electrochem. Soc. 2006, 27-32. [CrossRef]

53. Jian, L.; Bao-Rong, C.; Hou-Ming, Z. Effects of Washing and Heat-treatment on Structure and Electrochemical Charge/Discharge Property of LiNi0.8Co0.15Al0.05O2 Powder. J. Inorg. Mater. 2016, 31, 773-778. [CrossRef]

54. Lee, C.K.; Rhee, K.I. Reductive leaching of cathodic active materials from lithium ion battery wastes. Hydrometallurgy 2003, 68, 5-10. [CrossRef]

55. Seo, J.; Lee, J. Fast growth of the precursor particles of $\mathrm{Li}(\mathrm{Ni0} .8 \mathrm{Co} 0.16 \mathrm{Al} 10.04) \mathrm{O} 2$ via a carbonate co-precipitation route and its electrochemical performance. J. Alloys Compd. 2017, 694, 703-709. [CrossRef]

56. Agarwal, S.; Nekouei, F.; Kargarzadeh, H. Preparation of Nickel hydroxide nanoplates modified activated carbon for Malachite Green removal from solutions: Kinetic, thermodynamic, isotherm and antibacterial studies. Process Saf. Environ. Prot. 2016, 102, 85-97. [CrossRef]

57. Holzammer, C.C.; Finckenstein, A.; Will, S.; Braeuer, A. How Sodium Chloride Salt Inhibits The Formation Of CO2 Gas Hydrates. J. Phys. Chem. B 2016. [CrossRef] 
58. He, K.; Ruan, Z.; Teng, X.; Zhu, Y. Facile synthesis and electrochemical properties of spherical LiNi0.85-xCo0.15AlxO2 with sodium aluminate via co-precipitation. Mater. Res. Bull. 2017, 90, 131-137. [CrossRef]

59. Song, C.; Wang, W.; Peng, H.; Wang, Y.; Zhao, C.; Zhang, H. Improving the Electrochemical Performance of by LiAlO2 Surface Modification. Appl. Sci. 2018, 8, 378. [CrossRef]

60. Meng, H.; Zhou, P.; Zhang, Z.; Tao, Z.; Chen, J. Preparation and characterization of LiNi0.8Co0.15Al0.05O2 with high cyclingstability by using AlO2- as Al source. Ceram. Int. 2016, 43, 3885-3892. [CrossRef]

61. Wu, F.; Wang, M.; Su, Y.; Chen, S.; Xu, B. Effect of TiO2-coating on the electrochemical performances of LiCo1/3Ni1/3Mn1/3O2. J. Power Sources 2009, 191, 628-632. [CrossRef]

62. Shen, Y.; Eltzholtz, J.R.; Iversen, B.B. Controlling Size, Crystallinity, and Electrochemical Performance of Li4Ti5O12 Nanocrystals. Chem. Mater. 2013, 25, 5023-5030. [CrossRef]

63. Yudha, C.S.; Muzayanha, S.U.; Widiyandari, H.; Iskandar, F.; Sutopo, W.; Purwanto, A. Synthesis of LiNi0.85Co0.14Al0.01O2 Cathode Material and its Synthesis of LiNi0.85Co0.14A10.01O2 Cathode Material and its Performance in an NCA/Graphite Full-Battery. Energies 2019, 12, 1886. [CrossRef]

64. Liu, H.; Li, J.; Zhang, Z.; Gong, Z.; Yang, Y. The effects of sintering temperature and time on the structure and electrochemical performance of $\mathrm{LiNi0} .8 \mathrm{Co} 0.2 \mathrm{O} 2$ cathode materials derived from sol-gel method. J. Solid State Electrochem. 2003, 456-462. [CrossRef]

65. Subburaj, A.T.; Jo, Y.N.; Prasanna, K.; Kim, K.J.; Lee, C.W. Titanium oxide nanofibers decorated nickel-rich cathodes as high performance electrodes in lithium ion batteries. J. Ind. Eng. Chem. 2017. [CrossRef]

66. Kleiner, K.; Melke, J.; Merz, M.; Jakes, P.; Schuppler, S.; Liebau, V.; Ehrenberg, H. Unraveling the degradation process of $\mathrm{LiNi0} 8 \mathrm{Co} 0.15 \mathrm{Al} 0.05 \mathrm{O} 2$ electrodes in commercial Li-ion batteries by electronic structure investigations electrodes in commercial Li-ion batteries by electronic structure investigations. ACS Appl. Mater. Interfaces 2015, 7, 19589-19600. [CrossRef]

(C) 2019 by the authors. Licensee MDPI, Basel, Switzerland. This article is an open access article distributed under the terms and conditions of the Creative Commons Attribution (CC BY) license (http://creativecommons.org/licenses/by/4.0/). 